\title{
Analyzing the Ideology of Fox News Channel in Constructing Christchurch Mass Shooting
}

\author{
$1^{\text {st }}$ D Randy \\ Department of Communication Science, \\ Universitas Budi Luhur \\ Ciledug Raya, Petukangan Utara, \\ Pesanggrahan, South Jakarta, Indonesia \\ 12260 \\ *1871600035@student.budiluhur.ac.id
}

\author{
$2^{\text {nd }} \mathrm{N}$ Vera \\ Department of Communication Science, \\ Universitas Budi Luhur \\ Ciledug Raya, Petukangan Utara, \\ Pesanggrahan, South Jakarta, Indonesia \\ 12260
}

\begin{abstract}
Despite the 72 pages manifesto uploaded by Brenton Tarrant to social media before the deadly Friday attack, Fox \& Friends producers insisted on using the term "mosque shooting" in covering Christchurch mass shooting. It seems that there was resistance from the Fox \& Friends producers in using the term "terror" to label the attacks that left 51 people killed and 49 others injured. This study aims to examine and explore the ideology of Fox News Channel on the constructed reality of Christchurch shootings by analyzing the audio-visual content using Edelman's Frame Analysis method. The reality of mass shootings constructed by Fox \& Friends' producers tends to have a uniform model. In covering Christchurch shootings, the producers attempted to emphasize certain realities and direct public understanding based on conservative ideology. In conclusion, Fox News Channel ideology tends to be aligned with a certain party (Republican) ideology affiliated with the executive council. Also, Fox News Channel ideology influences its political and economic direction in herding and constructing public opinion.
\end{abstract}

Keyword-Christchurch Shooting, Fox News Channel, Frame Analysis, Media Construction of Reality, Media Ideology

\section{INTRODUCTION}

Lankford in Kessler (The Washington Post, 05/09/2018) explain that from 1966 to 2012, 292 mass shootings occurred in 171 [1]. Based on these data, the United States is on the top position with a total of 90 times or $1 / 3$ of total cases worldwide. According to Follman, Aronsen and Pan (Mother Jones, 31/08/2019), from January 2013 to August 2019, there were 53 other cases of mass shootings that occurred in the United States [2]. That means the mass shooting event has increased threefold in the past six years.

Dahmen et al. in Cassidy, La France, and Babin (2018, p. 4669) believe that the escalation in the number of cases of mass shootings led to an increase in the number of media reports about the event [3]. Cassidy, La France, and Babin (ibid) argue that the high frequency of mass shooting events ultimately impacts the pattern of media coverage. News about mass shootings is thought to be standardized and formulated. This standardization makes the news tend to be similar and discriminatory against a certain group. Therefore, Dahmen et al. (2017, p. 456) argue that certain journalists and scholars suggest that the formulaic nature of mass shooting coverage is problematic.

Quoting from Foxnews.com, Fox News Channel (FNC) is an American cable television channel owned by Fox Entertainment Group. FNC is news television which is a subsidiary of 21 st Century Fox. The main studio of FNC is located at 1211 Avenue of the Americas, New York City, New York. Former media consultant for the Republican Party, Roger Ailes has been the first CEO of Fox News Channel from October 7, 1996, to June 2016 (foxnews.com) [5].

According to La Monica (2009, p. 5), Fox News Channel has been accused of biased reporting and promoting the Republican Party [6]. Based on the study conducted by Mitchell et al. (Pew Research Center, 10/21/2014), Fox News as their main source for government and political news. Fox News is the most distrusted source among consistent liberals ( $81 \%$ distrust) [7]. Also, the primary source of Fox News reporting comes from government and political news. However, Fox News is the most unreliable source by consistent liberals (81\% distrust). The result of Martin and Yurukoglu's study (2017) shows, Fox News increases the share of Republican votes among viewers [8]. Fox News has succeeded in increasing the number of votes for Republicans in viewers in the 2016 presidential election. The data reinforces the existence of Fox News Channel's support for Republicans, so it can be assumed that both FNC and the Republicans have a similar ideology.

As is well known, Republicans have a conservative ideology that supports firearms ownership and tend to be less friendly to immigrants, especially Muslim immigrants in the United States. President Donald Trump's policy of immigration ban for visitors from 7 Muslim countries 
(Iran, Iraq, Libya, Somalia, Sudan, Syria and Yemen) was an indication of the Republican "anti-Muslim" ideology. $\mathrm{CNN}$ and The New Yorker, as well as international media such as Aljazeera and BBC, accused the controversial Travel Ban issued by President Trump on January 27, 2017, as a conservative anti-Muslim attitude.

Based on FNC's official website foxnews.com, in the third quarter of 2017, Fox \& Friends (aired 6-9 AM New York time) broke the record for most viewers in FNC history, reaching 1.5 million viewers [9]. As the most popular FNC program, Fox \& Friends has enormous potential in constructing people's understanding of reality, especially as it relates to mass shootings. In covering Orlando shooting, June 2016, Fox \& Friends producers justified the incident as an 'act of terror' less than 12 hours after the event. Fox \& Friends' producers also labelled the perpetrators as 'terrorists'. What is unique, in covering the Las Vegas shootings, editors used the term 'Las Vegas Mass Shooting', even though according to local police reports, it was and still is the deadliest massacre in modern American history. The incident killed 59 people (including the perpetrators) and injured 851 others, of whom 422 people got shot.

Similar to Las Vegas shooting, in covering the mass shootings in Christchurch, New Zealand, Fox \& Friends producers seem a bit resistance to using the term terror. Instead, they used the term 'Mosque Shooting', even though there was a 72 pages manifesto uploaded to social media by the perpetrator, Brenton Tarrant, explaining his motivation behind the attack. In framing the Christchurch shooting that killed 51 people and injured 49 others, it seemed that Fox \& Friends producers purposely chose certain words to construct the public understanding of reality.

\section{LITERATURE REVIEW}

\section{A. Media Ideology}

Silverblatt, Ferry and Finan $(2015$, p. 3) explain that an ideological approach to the study of media is designed to help people become more sensitive to ways in which the media reflect, reinforce, and shape ideological systems [10]. They added, ideology refers to the system of beliefs or ideas that help determine the thinking and behavior of a culture. Lull in Sobur (2015, p. 61) argues that ideology is a system of ideas expressed in communication; awareness is the essence of the attitudes, opinions, and feelings possessed by individuals or groups; while hegemony is the process by which the dominant ideology is conveyed. Hegemony forms awareness until finally, social power can work [11].

Eriyanto (2012, p. 146-147) explains, behavior and news produced by journalists are based on agreements or values that are understood together in the community [12]. He added (2012, p. 154), ideology does not always have to be associated with big ideas. Ideology can be interpreted as meaning or political significance. It means, the way a person sees events from a certain point of view, can also be defined as the broad meaning of ideology. Wiik in Lauk and Harro-Loit (2016, p. 1959) argued that professional journalists are part of an occupational community that possesses a particular symbolic resource- professional ideology [13]. Those professional ideas and standards are essential in constructing occupational identity. The ideology directs journalists on doing their daily work and decisions making. Based on the explanation, it can be concluded that the media ideology is a set of agreed values and serves as a benchmark for media journalists in producing news. The media's view of the world, as well as the nature and relationships between people, can construct public understanding and create false awareness.

\subsection{Media Construction of Reality}

Couldry and Hepp (2018, p. 15) explain that the media construction of reality is structured to reveal the role of the media that is deep, consistent, and mutually reinforcing their own organizations in the formation of the social world [14]. They believe the social world is not only mediated but also becomes an instrument of the media. The changes in dynamics and structures of the social world are part of the role played by the press continuously (indeed recursively) in its construction. According to them, everyday reality is a form of communication practice that dominates the social world and is influenced by institutional facts. In other words, institutions (media) construct the reality which is then spread and dominate the social world. In the end, the reality that was constructed by media becomes the reality that is consumed by the public every single day.

Yan (2019, p. 41) explains the two fundamental processes relating to media construction of social reality. The first is the selection of issues through a gatekeeping process based on news values. The second is defining and constructing the issues that have been selected [15]. According to Yan, to examine if the pictures that were taken by the media represent the reality, several questions must be answered. Whether reality entities (objects, events, processes, relations, etc.) exist independently of observations? How is the knowledge and meaning of them, generated and conveyed? [15] Then it can be concluded that media construction of the reality can be observed by questioning the entity for what is conveyed by the media, and how the entity is delivered.

From the explanation above, social world is something that is built by humans. Mass media construct the reality that is widely distributed to dominate our social world. In the end, the reality that was constructed by media becomes the reality that is consumed by the public every day. Media construction of reality can be examined by observing the entity of a reality displayed by the media, and how the entity is conveyed to the public.

\section{B. Media Frame}

According to Edelman (1993, p. 231), the social world is a kaleidoscope of potential realities, which can be easily generated by changing the ways in which observations are framed and categorized [16]. He added that the classification scheme is, therefore, the central of political maneuvering and political persuasion. He aligns framing as a categorization technique, directing certain perspectives by using certain words that indicate how facts or reality are understood.

Eriyanto (2012, p. 186) explains, categorization in 
Edelman's view is an abstraction and function of thought. Category, helps humans understand the diverse and irregular reality into a reality that has meaning [12]. Thus, categorization can be interpreted as a simplification of complex reality so that it can be understood by emphasizing one side or dimension and overriding other sides. Categorization is a tool of how reality is understood and present in the minds of the public. The alternative categorization can change the meaning. According to Tewksbury and Scheufele in Bryant and Oliver (2009, p. 17), Edelman's news framing theory helps the public understand political practices in manipulative words and symbols [17].

\section{FINDING AND DISCUSSION}

\section{A. The History of Fox News Channel}

Based on Fox News Channel (FNC) official website, FNC is a 24-hour all-encompassing news service dedicated to delivering breaking news as well as political and business news [5]. The company claims to be the number one cable television network in the USA. According to the Suffolk University poll published by foxnews.com, FNC has become the most-watched television news channel for the past 15 years [5]. FNC is a subsidiary of the 21 st Century Fox Group. It claims to dominate the cable news landscape with a reach of up to 90 million families. Since October 7, 1996, the FNC operates using two satellites, namely: Galaxy 17 Transponder 6 and Galaxy 15 Transponder 2. The headquarter is on 1211 Avenue of the Americas, New York, NY 10036. FNC also has branch offices spread across 14 cities in the world, namely: Atlanta, Boston, Chicago, Dallas, Denver, Jerusalem, London, Los Angeles, Miami, Paris, Rome, San Francisco, Seattle, and Washington DC [5].

Stempel III and Hargrove (2015, p. 173) explain that Fox News Channel was created in 1996 by Australianborn U.S. media entrepreneur Rupert Murdoch [18]. He appointed Roger Ailes, former media strategist for Republican Party who personally directed Richard Nixon's 1968 campaign, as CEO of the cable and satellite all-news channel. Fox News has become America toprated cable news channel. The channel has been widely criticized as showing a conservative bias despite its slogan 'fair and balanced' reporting [18]. Stempel III and Hargrove (ibid) continued, Murdock built a news empire that began with newspapers in Australia and New Zealand in the 1950s and 1960s, expanded to England by acquiring News of the World and The Sun 1969, and finally The Times of London in 1981 [18]. Murdock then became a naturalized US citizen in 1985 when he purchased Twentieth Century Fox, followed by HarperCollins publisher in 1989 and The Wall Street Journal in 2007. Stempel III and Hargrove added, although British cable operations are not very profitable, Mudrock wants to challenge the American Cable News Network and keep Ailes away from the -America's Talking- cable channel, which eventually becomes MSNBC's rival [18]. Based on those data, it is known that Fox News Channel is part of an international media network owned by Rupert Murdoch. The media network led directly by Murdoch is spread across several countries including Australia, France, Germany, Luxembourg, New Zealand, United Kingdom, and the United States.

Fox \& Friends is one of the programs that air on Fox News Channel. In a statement published on foxnews.com, FOX \& Friends (6-9 AM/ ET), is on pace to have its highest-rated year in network history, delivering 1.5 million total viewers during the third quarter of 2017 [18]. The program, which runs on weekdays, is hosted by Abby Huntsman, Ainsley Earhardt, Brian Kilmeade, and Steve Doocy. On its official website, Fox News Channel claims that since 2001, Fox \& Friends is the defending champion for the number 1 Cable Television Program award in the United States. So, it is probable that Fox \& Friends becomes the standard reference for other morning news programs.

\section{B. Fox News Channel's Vision and Mission}

Stempel III and Hargrove (2015, p. 173) explain that Fox News Channel (FNC) is a 24-hour all- encompassing news service dedicated to delivering breaking news as well as political and business news [18]. The statement can be found on the Foxnews.com website, but there is no explicit statement about the mission of Fox News Channel as an institution. Foxnews.com official website also does not declare the vision of Fox News Channel, but on the Fox Nation (FN) page, the authors found a statement below:

The Fox Nation was created for people who believe in the United States of America and its ideals, as expressed in the Constitution, the Declaration of Independence, and the Emancipation Proclamation. It is a community that believes in the American Dream: life, liberty, and the pursuit of happiness. One that believes being an American is an honor, as well as a great responsibility - and a wonderful adventure. This is a place for people who believe we live in a great country, a welcoming refuge for legal immigrants who want to contribute their talents and abilities to make our way of life even greater. We believe we should enjoy the company and support of each other, delighting in the creativity, ingenuity, and work ethic of one and all, while observing the rules of civility and mutual respect and, most importantly, strengthening our diverse society by striving for unity (nation.foxnews.com) [19].

Stempel III and Hargrove explain that Fox News Channel has the slogan which is "fair and balanced reporting'. It is also explicitly illustrated in paragraph 3 on the official Fox Nation website. Thus, the authors assume that Fox Nation and Fox News Channel have the same vision and mission.

\section{Frame Analysis Finding}

- Title : Survivor describes New Zealand
mosque shooting.
- Date : Friday, March $15,2019$.
- Duration : 3 minutes, 2 seconds.
- Results :
On this particular news package, Fox \& Friends On this particular news package, Fox \& Friends
roducers select and process the information available, compile and use certain words to bring public attention to 
the number of victims, the sequence of events, the efforts of the local community and the medical professionals in saving the victims, and the New Zealand and the American government's responses to the incident. Presumably, to minimize the bias in reporting about Christchurch mass shooting, the producers make Kitty Logan, a Fox News Channel contributor in London explaining about the event.

Logan (00:42-00:54) opens her statement with the terms "shootings" and "attacks". Within a period of 17 seconds (01:45-02:04), Logan gave an explanation about the perpetrators as follows:

AUTHORITIES HAVE NOT NAMED THE SUSPECT, BUT AN AUSTRALIAN MAN IS BEING LINKED TO THE ATTACK. HE ALSO POSTED AN ANTI IMMIGRATION MANIFESTO IN WHICH HE CLAIMED RESPONSIBILITY. A GRAPHIC VIDEO OF THE ATTACK WAS ALSO POSTED ONLINE FACEBOOK LATER REMOVED IT. POLICE SAID NONE OF THESE SUSPECTS WERE ON ANY KIND OF TERROR WATCH LISTS (Fox \& Friends, 13/06/2019) [20].

Logan emphasized several realities, namely:

O The alleged perpetrators are Australian citizens.

o The perpetrator uploaded an anti-immigration manifesto in which he claimed responsibility for the attack.

- Uncensored assault videos were uploaded to Facebook and have been deleted.

- The alleged perpetrators are not on the terror surveillance list.

In the next 9 seconds (02:05-02:14), Logan explained how many victims were injured and what kind of treatment they have received.

NOW AT LEAST 20 PEOPLE WERE ALSO INJURED

IN THIS ATTACK. THEY WERE RUSHED TO HOSPITAL FOR EMERGENCY TREATMENT (Fox \& Friends, 13/06/2019) [20].

While in the last 47 seconds (02:15-03:01), Logan explained about the police's appeal to local residents, as well as the response and action of American solidarity delivered by White House spokeswoman, Sarah Sanders.

- Frame Explanation :

Based on Edelman Frame analysis model, Fox \& Friends placed themselves on our side (US) by opening the news with a snippet from the press release of New Zealand Prime Minister Jacinda Arden, followed by President Trump's comments on Twitter about the mass shooting event in Christchurch. The alleged perpetrators are on our side because they have a similar ideology as Fox News Channel, which have firearms and antiimmigrants. This can be seen on Logan's hesitation in labelling the perpetrators as terrorists. "NONE OF THESE SUSPECTS WERE ON ANY KIND OF TERROR WATCH LISTS” (Fox \& Friends, 13/06/2019) [20].

Meanwhile, Muslims and victims who were attending Friday Prayers in the two mosques are in the opposite category (THEM) because of differing ideological views in terms of religion and stereotyped as non-white immigrants. This can be seen from the selection of survivor to provide information about the incident, as well as photographs of victims (people of color) and families (using the hijab) that aired.

\section{Discussion}

Based on the data collected by the authors on the historical background of Fox News Channel, the vision and mission of the organization, as well as the closeness of the FNC executive council with certain parties, it is known that Fox News Channel tends to have an ideological closeness with the Republican Party. Murdoch's naturalization event through investment in the reign of President Reagan (Republican Party) in 1985 was also widely associated with the 1970 White House memo which recorded the implantation strategy of President Nixon and Ailes's GOP agenda through news television.

Murdoch's naturalization was considered odd because it took place five years before the regulation on "citizenship by investment" was issued by President Bush Senior (Republican Party) in 1990. Given that Ailes was the media expert for the presidential candidates from the Republican Party, he was allegedly involved in smoothing citizenship granted to Murdoch. This seemed to be validated by Murdoch decision in choosing Ailes as the first CEO of Fox News Channel since 1996-2016.

The frame constructed by Fox \& Friends' Producers on the news about Christchurch shootings shows the attempt to emphasize certain realities and direct public understanding based on conservative ideology. This can be seen from the resistance of Fox \& Friends producers to display the part where Jacinda Arden, Prime Minister of New Zealand, stated that the incident was a terror attack. Instead, the producers decided to cut the press release after the following statement: "THIS IS ONE OF THE LASTEST DAYS OF NEW ZEALAND. EXPLAINING WHAT HAS HAPPENED HERE IS AN OUTSTANDING VIOLENCE" (Fox \& Friends, 13/06/2019) [20].

Besides the hesitation on broadcasting the part where Arden condemned the acts of terror committed by the perpetrators, Fox \& Friends producers also displayed President Trump's response on Twitter which called the attack as a mass shooting. Presumably, Fox \& Friends producers followed President Trump's statement by choosing the words such as; gunfire, shootings and assault with firearms on reporting the Christchurch incident. The term terror only appears once in the whole news package. It was also used to ostensibly protect/clear the name of the offenders through the statement: "NONE OF THESE SUSPECTS WERE ON ANY KIND OF TERROR WATCH LISTS" " (Fox \& Friends, 13/06/2019) [20].

Of all the 72 pages manifesto posted by the perpetrator, Fox \& Friends producers chose to highlight "HE ALSO POSTED AN ANTI IMMIGRATION MANIFESTO IN WHICH HE CLAIMED RESPONSIBILITY." Even though the manifesto explains other reasons why the perpetrator carried out the attack. In fact, the perpetrator also stated a strong opinion on crusade and left anti-Muslim remarks. To put it on perspective, Federal Bureau of Investigation (2009) divided terrorism into two categories, namely: domestic and international terrorism. Domestic terrorism is defined 
as an act of violence, a crime committed by individuals and/ groups for ideological purposes that comes from domestic influences, such as those that are political, religious, social, racial, or environmental [21]. Whereas international terrorism is an act of violence, a crime committed by individuals and/ groups inspired by, or related to a designated foreign terrorist organization or state. Based on that definition, Fox \& Friends producers should be able to label the mass shooting in Christchurch, New Zealand as an act of terror.

However, based on the findings, it is known that media ideology influences the political and economic direction of the media in constructing a reality. Generally, the ideology of media institutions is in line with the ideology of media owners and/or investors. Hence, it is possible that media ideology will change according to the ideology of the authorities. Nevertheless, in the case of Fox News Channel, the reality of mass shootings constructed by the producers tends to have a uniform model. It indicates the consistency of media ideology from time to time, regardless of who or what ideology came to power in America at the time of the mass shooting.

\section{CONCLUSION}

The ideology of mass media is a set of values agreed upon by media journalists and is used as the main benchmark in producing news. This ideology then influences the political and economic direction of the media in herding and constructing public opinion. Based on research findings, the ideology of Fox News Channel tends to be aligned with party ideology affiliated with the executive council.

In constructing the reality of the mass shooting incident, the producers of Fox News Channel tend to have uniform reporting patterns. These findings indicate the Fox News Channel consistency in covering the news about mass shooting incidents, regardless of who or what ideology came to power in America when the event occurred. That is, the ideology of Fox News Channel influences reporting, but government regulation does not sufficiently influence the ideology of Fox News Channel.

Based on the results of the study, the authors recommend the Fox News Channel producers to be more objective in compiling news especially those related to mass shooting incidents that occurred in the United States and other countries. The tendency of the direction of reporting is necessary, but the bias that forms a stereotype needs to be avoided to minimize the potential for public discrimination against a race, ethnicity, and/ religion. To the researchers, the authors suggest doing more in-depth and comprehensive research to control the function of the media as a public broadcasting institution. Similar research is also useful as an academic study in balancing and criticizing constructed reality framed by mass media.

\section{REFERENCES}

[1] Kessler G 05/09/2018 Does the U.S. lead the world in mass shootings? (USA: The Washington Post) washingtonpost.com/politics/2018/09/05

[2] Follman M, Aronsen G and Pan D 31/08/2019 A Guide to Mass Shootings in America (USA: Mother Jones) motherjones.com/politics

[3] Cassidy W P, La France B H and Babin S 2018 Routine
Adjustments: How Journalists Framed the Charleston Shooting (International Journal of Communication 122018) pp 4668-4688

Dahmen N S et al. 2017 Covering Mass Shootings (Journalism Practice vol 12:4), pp 456-476 DOI: $10.1080 / 17512786.2017 .1326832$

[5] Fox News Channel Corporate Information http://press.foxnews.com/

[6] La Monica P R 2009 Inside Rupert's Brain (Bern: Peter Lang) https://books.google.ae/booksHO

[7] Mitchell A, Gottfried J, Kiley J and Matsa K E 2014 Political Polarization \& Media Habits (Pew Research Center: Journalism \& Media Analysis) journalism.org/2014/10/21/media-habits/

[8] Martin G J and Yurukoglu A 2017 Bias in Cable News: Persuasion and Polarization. (American Economic Review vol 107:9) pp 2565-99

[9] Fox News Channel 2017 Fox News Channel Continues its Reign as the Most-Watched Basic Cable Network for 16 Consecutive Months in Total Daypress.foxnews.com/2017

[10] Silverblatt A, Finan B and Ferry J 2015 Approaches to Media Literacy A Handbook (London: Taylor \& Francis) https://www.google.com/zXRsBgAAQBAJ?hl

[11] Sobur A 2015 Analisis Teks Media: Suatu Pengantar untuk Analisis Wacana, Analisis Semiotik, dan Analisis Framing (Bandung: PT REMAJA ROSDAKARYA)

[12] Eriyanto 2012 Analisis Framing: Konstruksi, Ideologi, dan Politik Media (Yogyakarta: PT LKiS Printing Cemerlang)

[13] Lauk E and Harro-Loit H 2016 Journalistic Autonomy as a Professional Value and Element of Journalism Culture: The European Perspective (International Journal of Communication vol 11) pp 1956-1974 https://ijoc.org/index.php/ijoc/article/view/5962/2018

[14] Couldry N and Hepp A 2018 The Mediated Construction of Reality (US: John Wiley \& Sons) https://books.google.co.uk/books?id=yJ9RDwA

[15] Yan F 2019 Image, Reality and Media Construction: A Frame Analysis of German Media Representations of China (Singapore: Springer Nature) https://books.google.ae/7yxDwAAQ

[16] Murray E 1993 Contestable categories and public opinion (Journal of Political Communication vol 10:3) pp 231-242 tandfonline.com/doi/10584609

[17] Bryant J and Oliver M B 2009 Media effects: Advances in theory and research 3rd ed (London: Taylor \& Francis) https://www.google.com/books/Media_Effects/2BeOA

[18] Stempel III G H and Hargrove T K 2015 The 21st-Century Voter: Who Votes, How They Vote, and Why They Vote [2 volumes] (California: ABC-CLIO)

[19] Fox News Channel Our Purpose https://nation.foxnews.com/our-purpose

[20] Hadden IV G 13/06/2019 Survivor describes New Zealand mosque shooting (USA: Fox \& Friends, Cable Television Broadcasting youtube com/watch? $\mathrm{v}=$ DUk0EHSNVx 8

[21] Federal Bureau of Investigation Terrorism fbi.gov/terrorism 